\title{
Fine Structure of the Dorsal Organ of the House Fly Larva, Musca domestica L.
}

\author{
I-Wu Chu and R. C. Axtell * \\ Department of Entomology, North Carolina State University, Raleigh, N.C., U.S.A
}

Received November 12, 1970

Summary. The dorsal organs of the cephalic lobes of the house fly larva, Musca domestica L. were studied by light, scanning and transmission electron microscopy. Five types of receptors were found in the distal part of the dorsal organ: (1) The dome, whose ultrastructure is similar to that of thin-walled pegs, is assumed to be an olfactory receptor. (2) A lateral pore receptor, with the distal tips of two dendrites exposed to the exterior through a pore, is presumed to be a contact chemoreceptor. (3) A scolopidium-like receptor, with an ultrastructure characteristic of a scolopidium receptor except that the dendrite might be exposed to the exterior through an opening, is assumed to be both a mechanoreceptor and contact chemoreceptor. (4) Two receptors, each with one of its two dendrites exposed to the exterior, are probably contact chemoreceptors. (5) Two unclassified receptors, each with one dendritic tip exposed to the exterior and the other dendrite with a tubular body ending near the pore, may serve as both contact chemoreceptors and mechanoreceptors. The last four types are located in the invagination between the dome and the cylindrical portion of the dorsal organ. The seven basal pores of the dome are apparently points of origin of the scolopales and have no sensory function. The dorsal organ is supplied by 35-41 bipolar neurons, indicating the possibility of additional undescribed receptors.

Key Words: Sensory receptors - Insecta - Diptera — Ultrastructure.

\section{Introduction}

The first detailed investigation of the sense organs of the anterior end of house fly larvae, Musca domestica L. (Diptera: Muscidae), was made by Bolwig (1946) who also reviewed the earlier literature. He found three pairs of sense organs on the cephalic lobes and called them the dorsal, terminal and ventral organs. Bolwig presented behavioral data indicating that the dorsal organs are responsible for olfaction but openings in the cuticle could not be detected by light microscopy. Earlier workers assumed the dorsal organ was a light receptor. Ludwig (1949) investigated the embryology and morphology of Calliphora erythrocephala Meigen and stated that the position of the three pairs of anterior sensory organs in the larvae corresponds to that of the imaginal sense organs. Ludwig assumed that the dorsal organs of the larvae correspond to the antennae of the adult and called them the "antennal sense organs". In the present study, we adopted the terms used by Bolwig (1946).

Richter (1962) was the first to study the fine structure of the dorsal organ ("Antennensinnesorgan") of a fly larva (Calliphora erythrocephala) by means of

* The authors thank Dr. E. H. Slifer for preparation of the $\mathrm{AgNO}_{3}$ treated whole larvae, valuable discussions and review of this manuscript and Dr. R. F. Foelix for assistance and advice. This research was supported in part by the Office of Naval Research, PHS Research Grant EC-246 and NIH Training Grant ES-00069. Paper No. 3329 of the North Carolina State University Agricultural Experiment Station journal series.

2 Z. Zellforsch., Bd. 117 
electron microscopy. She gave a detailed description of the dome (distal part of the dorsal organ) and demonstrated fine canals and pores in the cuticle and branching dendrites inside.

Our investigation of the dorsal organ of house fly larvae has revealed four other types of receptors, in addition to the dome.

\section{Materials and Methods}

The cephalic lobes of house fly larvae (Musca domestica L.; third-instar) were fixed for electron microscopy at $4^{\circ} \mathrm{C}$ for 20 hours in $5 \%$ glutaraldehyde with $0.15 \mathrm{M}$ sucrose in a $0.05 \mathrm{M}$ sodium-cacodylate buffer at PH 7.4, and then washed three times in a cold sodium-cacodylate buffer with $0.3 \mathrm{M}$ sucrose. The material was post-fixed for 2 hours in $1 \% \mathrm{OsO}_{4}$ with veronalacetate buffer (Palade, 1952) and embedded in Epon 812 epoxy resin over propylene oxide after dehydration with ethanol. Sections cut with a diamond knife on a Reichert Om U 2 ultramicrotome were mounted on formvar-coated copper grids and stained with uranyl acetate (in 50\% ethanol) and lead citrate (Venable and Coggeshall, 1965) for 20-30 minutes each. Observations were made with a Siemens Elmiskop $1 \mathrm{~A}$.

For permeability studies at the ultrastructural level, living larvae were immersed in $2 \%$ silver-protein solution (Ernst, 1969) for 1 hour, washed with distilled water, fixed and embedded as above. Sections, 1-1.5 $\mu$ thick, were stained for light microscopy with basic fuchsin and methylene blue-azure B (Richardson et al., 1960). Alcohol-preserved larvae were immersed in a $1 \% \mathrm{AgNO}_{3}$ solution for varying times (3 min to $2 \mathrm{hrs}$ ) in order to identify exterior openings of particular receptors by light microscopy.

For surface structure and three-dimensional distribution of sensory organs, cephalic lobes of house fly larvae were examined with a JEOL JSM-2 scanning electron microscope (SEM). The best results were obtained with unfixed whole larvae coated with gold-palladium in a vacuum evaporator.

\section{Results}

The sensory organs are situated on the anterior end of the cephalic lobes, giving the tip of the larva a cleft appearance. Each lobe has three different sensory organs (Fig. 1) which Bolwig (1946) designated as the dorsal, terminal and ventral organs.

The dorsal organ consists of the "dome" and the "cylindrical portion" (Figs. 2, 3). The dome is approximately $15 \mu$ in diameter at the base and $16 \mu$ in height. The dome wall, $0.5 \mu$ thick, consists of sclerotized epicuticle (Bolwig, 1946). At the dome base, this cuticular wall expands forming a rim (2.7 $\mu$ thick) towards the inside. Seven basal pores $(0.8 \mu$ in diameter and $1.2 \mu$ in depth) are located about equidistant around the circumference in the thick wall of the dome base (Fig. 4). The entire dome wall above the level of the cuticle rim is perforated by a pore-tubule system.

The cylindrical portion is $30 \mu$ long, elliptical in cross-section $(25 \times 34 \mu)$ and coated by two concentric cuticular envelopes (Figs. 2, 3, 5). The outer envelope, composed of epicuticle, exocuticle and endocuticle, is separated by a narrow fluid-filled space from an inner cuticular ring ( $25 \mu$ long). The inner ring, composed of sclerotized mesocuticle (Richter, 1962) is thinner at the lateral side than in the other area $(2.5 \mu$ thick). A soft lamellar endocuticle, which is continuous with the outer cuticular envelope, connects the dome and the cylindrical portion. This junction is marked by an invagination of the cuticle.

The dorsal organ is supplied by 35-41 bipolar neurons which together with their accessory cells form a ganglion in the interior of the cephalic lobe (Fig. 2). 


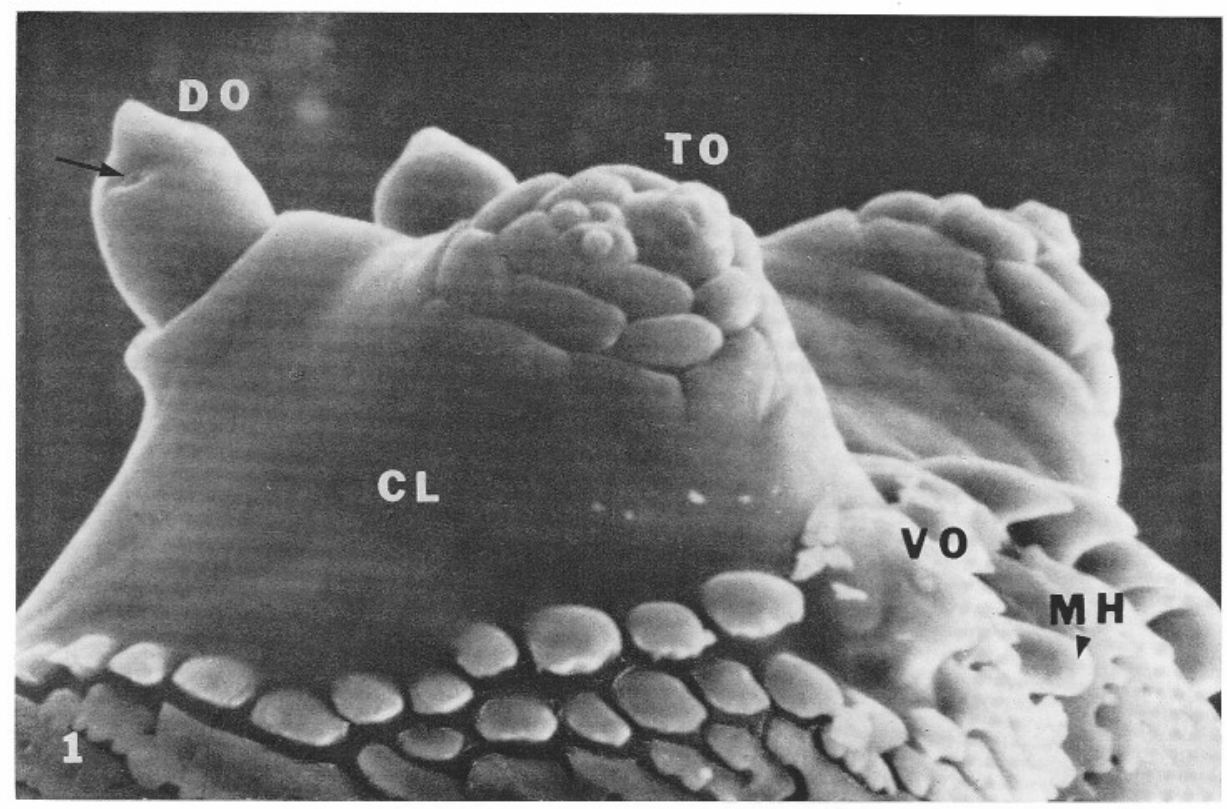

Fig. 1. Lateral-ventral view of the cephalic lobes $(C L)$ of the house fly larva showing the dorsal organ $(D O)$, terminal organ $(T O)$ and ventral organ $(V O)$. $M H$ mouth hook; arrow, lateral pore receptor. SEM, $\times 450$

\section{Sensory Receptors}

The dorsal organ contains five different types of receptors located in the distal part of the organ (Fig. 3): (1) the dome, (2) a lateral pore receptor (3) a scolopidium-like receptor, (4) two contact chemoreceptors, and (5) two other unclassified receptors. The last four types are located in the invagination between the dome and the cylindrical portion.

Dome. The dome is innervated by 21 bipolar neurons (Figs. 2, 3). Their dendrites form seven bundles, of three dendrites each, entering the cylindrical portion (Figs. 5, 6). About $7 \mu$ below the base of the cylindrical portion, each dendrite is subdivided by a constricted region into an inner (proximal) and an outer (distal) segment (Figs. 7, 8). A modified ciliary structure and a fibrillar body (Smith, 1969) are observed in this region. Just proximal to the constriction lie two inconspicuous basal bodies, one behind the other. Periodically striated rootlets arise from the proximal ends of these two basal bodies and extend down into the inner segment whereas short ciliary tubules arise from the distal basal body and continue upward. The cytoplasm of the outer segment contains neurotubules and sometimes a few small vesicles. Mitochondria, vesicles and sparse neurotubules are present in the inner segment. Neurofilaments are found in both the inner and the outer segments (Fig. 6). A typical feature in the ciliary region is the presence of multivesicular bodies which occur in close vicinity of the constriction in both the inner and the outer segment (Figs. 7-9). Similar multivesicular bodies have been reported in the ciliary region of chemoreceptors in a cockroach (Moulins, 1968). 


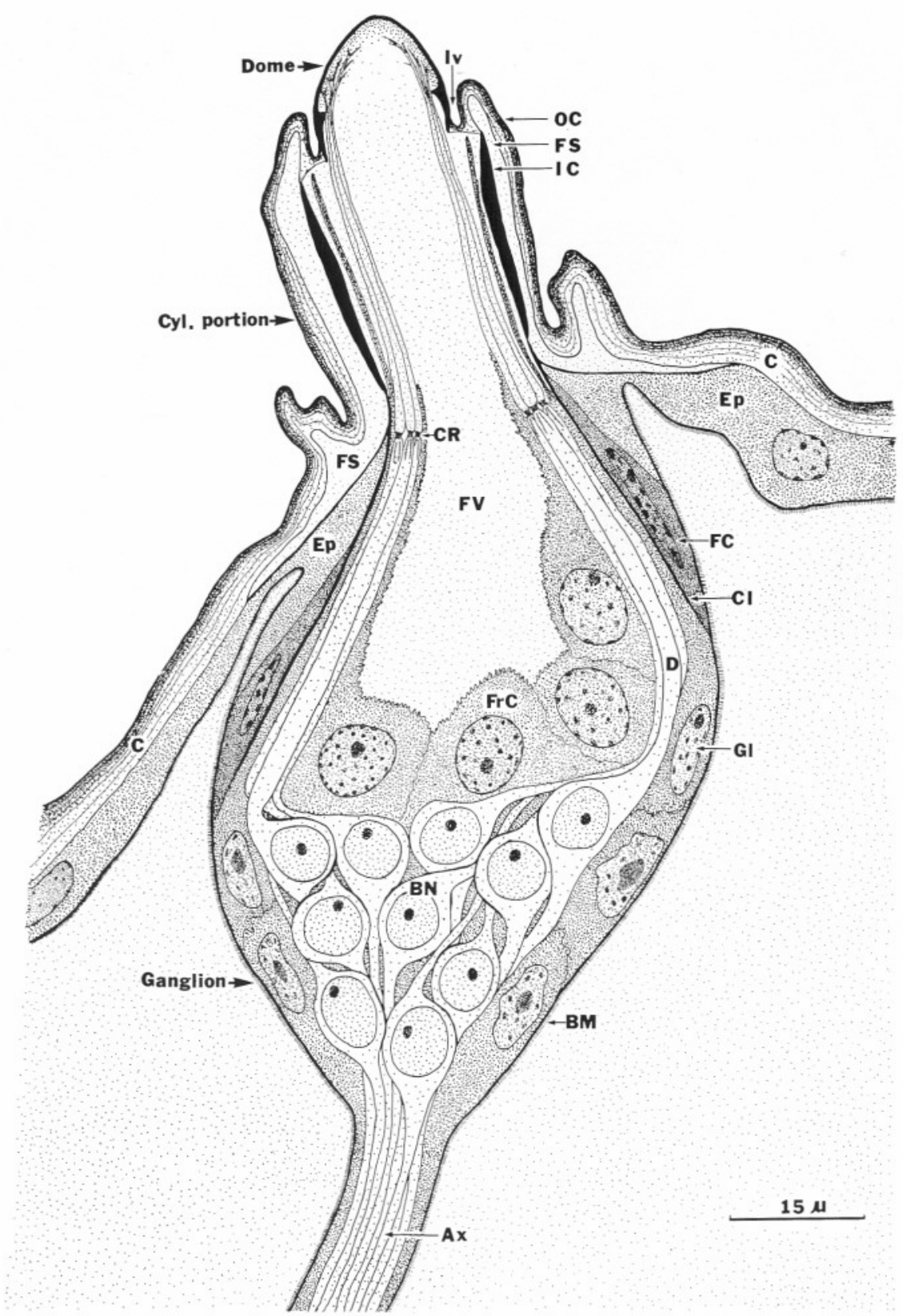

Fig. 2. Diagram of a longitudinal section of the dorsal organ (lateral pore receptor not shown). $A x$ axon, $B M$ basement membrane, $B N$ bipolar neuron, $C$ cuticle, $C I$ cuticular invagination, $C R$ ciliary region, $D$ dendrite, $E p$ epidermis, $F C$ flattened cell, $F r C$ formative cell, $F S$ fluidfilled space, $F V$ fluid-filled vacuole, $G l$ glial cell, $I C$ inner cuticular ring, $I v$ invagination, $O C$ outer cuticular ring. (Figs. 2 and 3 drawn by $\mathrm{I}-\mathrm{Wu} \mathrm{Chu}$ ) 

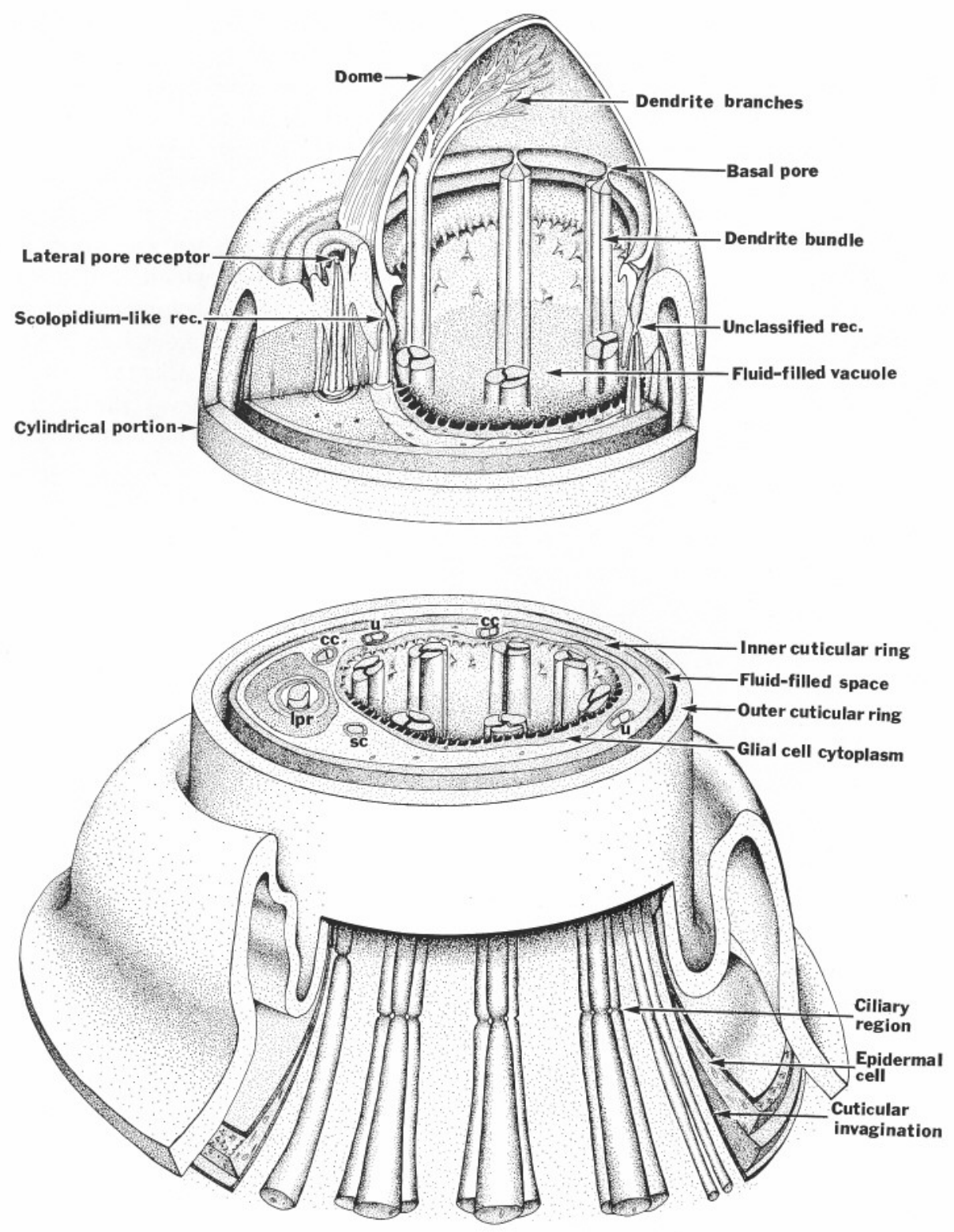

Fig. 3. Diagram of the dorsal organ showing the distribution of receptors. $c c$ contact chemoreceptor, $l p r$ lateral pore receptor, $s c$ scolopidium-like receptor, $u$ unclassified receptor

About $5 \mu$ distal to the constriction, each dendrite is enveloped by an electrondense scolopale which extends through the cylindrical portion up to a basal pore of the dome. Each bundle of three dendrites passes close to a basal pore (Figs. 4, $10,11)$, but does not appear to be exposed to the exterior. Evidence for this 
conclusion was obtained by immersing living larvae in $2 \%$ silver-protein solution for 1 hour before preparation for electron microscopy. If the dendrites were connected to the exterior through the basal pores, one would expect to find silver granules diffused into the lumen of the dome through the basal pores. In our preparation, the silver granules tended to accumulate in the neck of the

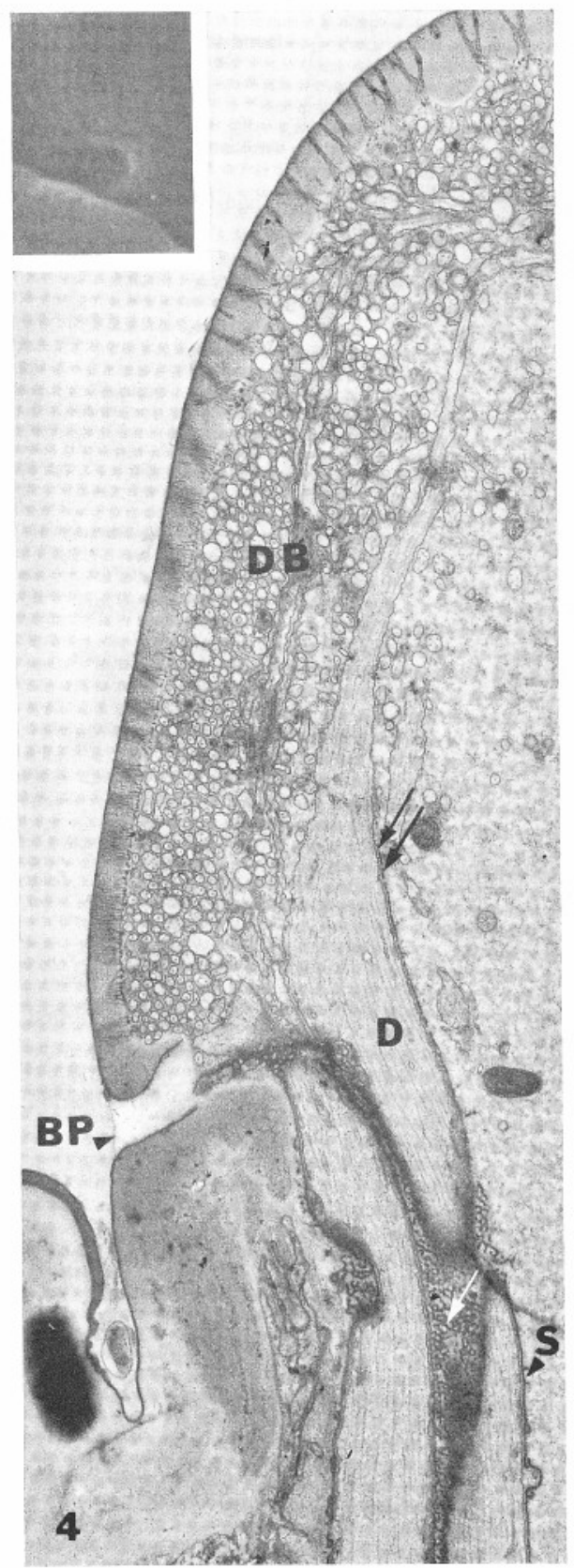
basal pore (Fig. 11) without penetrating to the interior. The scolopales within one bundle of dendrites are interconnected by branches which arise from the surface of each scolopale (Fig. 4). Frequently, two scolopales fuse in the distal part of the dendrites (Fig. 10).

Distal to the basal pores, the dendrites start branching. The end of the scolopale breaks up into a loose mesh work before vanishing completely above the level of the basal pores (Fig. 4). Therefore, the peripheral lumen of the dome is filled with naked dendritic branches bathed in a fluid. The smallest dendritic branches are about $800 \AA$ in diameter and contain only one neurotubule.

The dome wall $(0.5 \mu$ thick $)$ is perforated by numerous pore tubules arranged in rows (Figs. 12, 13). Each row consists of 5-6 tubules in the basal part which gradually fuse into two before terminating in a ditch-like furrow on the surface. These furrows (120 $\AA$ in width) are oriented toward the long axis of the dome and give the surface of the wall a striated appearance (Fig. 4, insert). An electron-dense line can be observed in those minute furrows (Figs. 13b, 15a). Perhaps the

Fig. 4. Longitudinal section of the dome showing three dendrites $(D)$ passing the basal pore $(B P)$ and entering the dome. Scolopales $(S)$ surrounding each dendrite are interconnected by branches (white arrow) which arise from the surface of each scolopale. Above the basal pore, the scolopale breaks up and gradually disappears (arrows). $D B$ dendritic branches. $\times 25200$. Insert: Basal pore. SEM, $\times 8300$ 


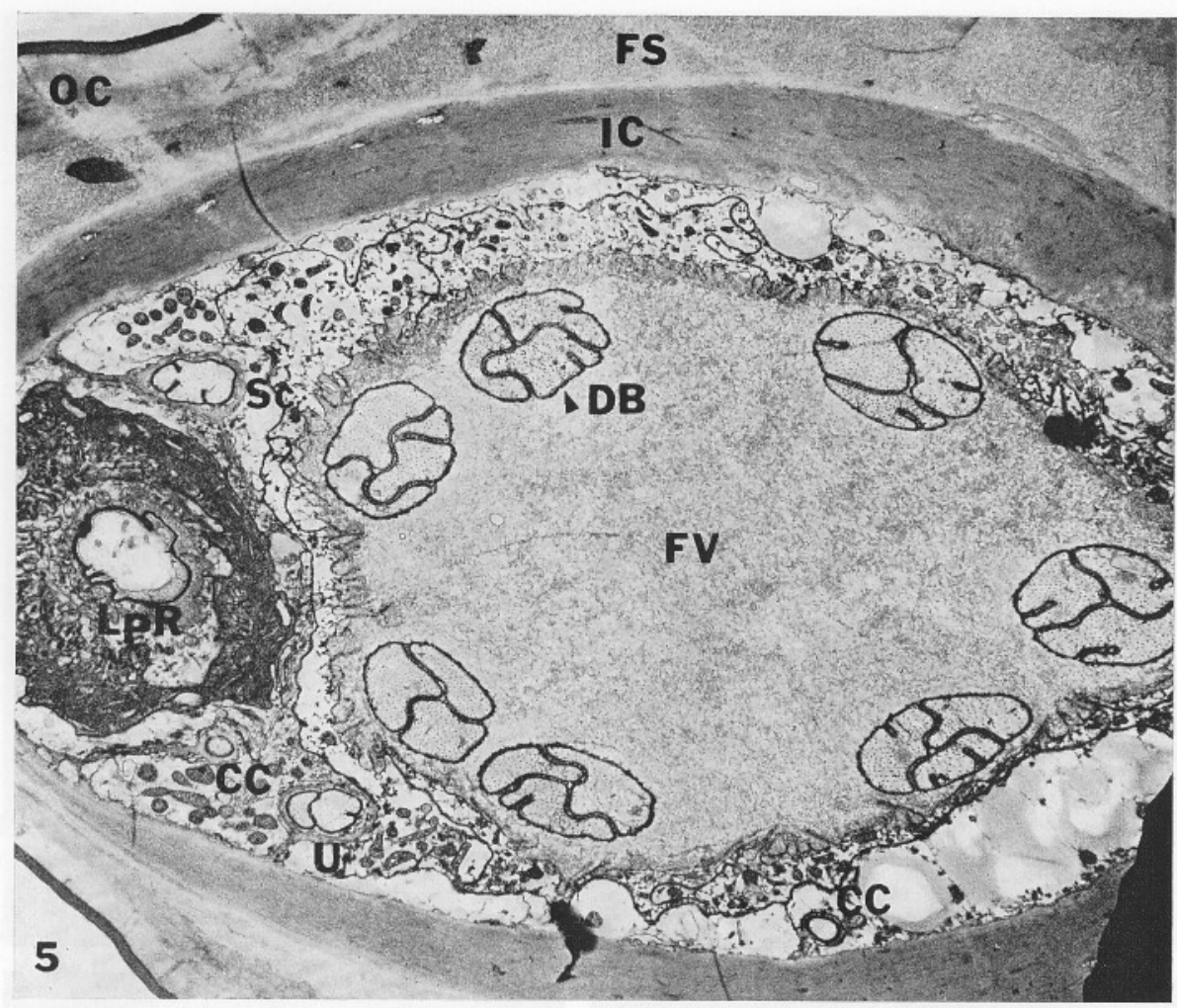

Fig. 5. Transverse section through the middle part of the cylindrical portion. Seven dendritic bundles $(D B)$ composed of three dendrites each, innervate the dome. $C C$ dendrite of the contact chemoreceptor, $F S$ fluid-filled space, $I C$ inner cuticular ring, $L P R$ two dendrites of the lateral pore receptor, $O C$ outer cuticular envelope, $S c$ dendrite of the scolopidium-like receptor, $U$ dendrites of the unclassified receptor. $\times 5550$

electron-dense filaments inside the $120 \AA$-diameter pore tubules (Fig. 13c) fuse to form this line. An unstained transverse section of the dome (Fig. 14) shows the pore-tubule system as being electron-dense and differing markedly from the very light appearing dendritic branches. Therefore, we assume that pore tubules are of a different nature from dendritic branches. No direct connection between the dendritic branches and pore tubules was observed. Some electron-dense extensions of the pore tubules are located beneath the dome wall. A conspicuons feature of the pore-tubule system is some material of low electron density, presumably a fluid, inside the inner part of the pore tubules (Fig. 15a). Small silver granules can pass through the pore-tubule system into the lumen of the dome (Fig. 15b). This strongly indicates that the pore-tubule system forms a pathway between the dendritic branches inside the dome and the exterior.

The dome surface is about $350 \mu^{2}$ (calculated from an assumed paraboloid of $11 \mu$ in height and $15 \mu$ in diameter) and approximately 860 pore tubules were counted in $1 \mu^{2}$. Accordingly, the entire cuticular dome wall is perforated by approximately 300000 pore tubules. 

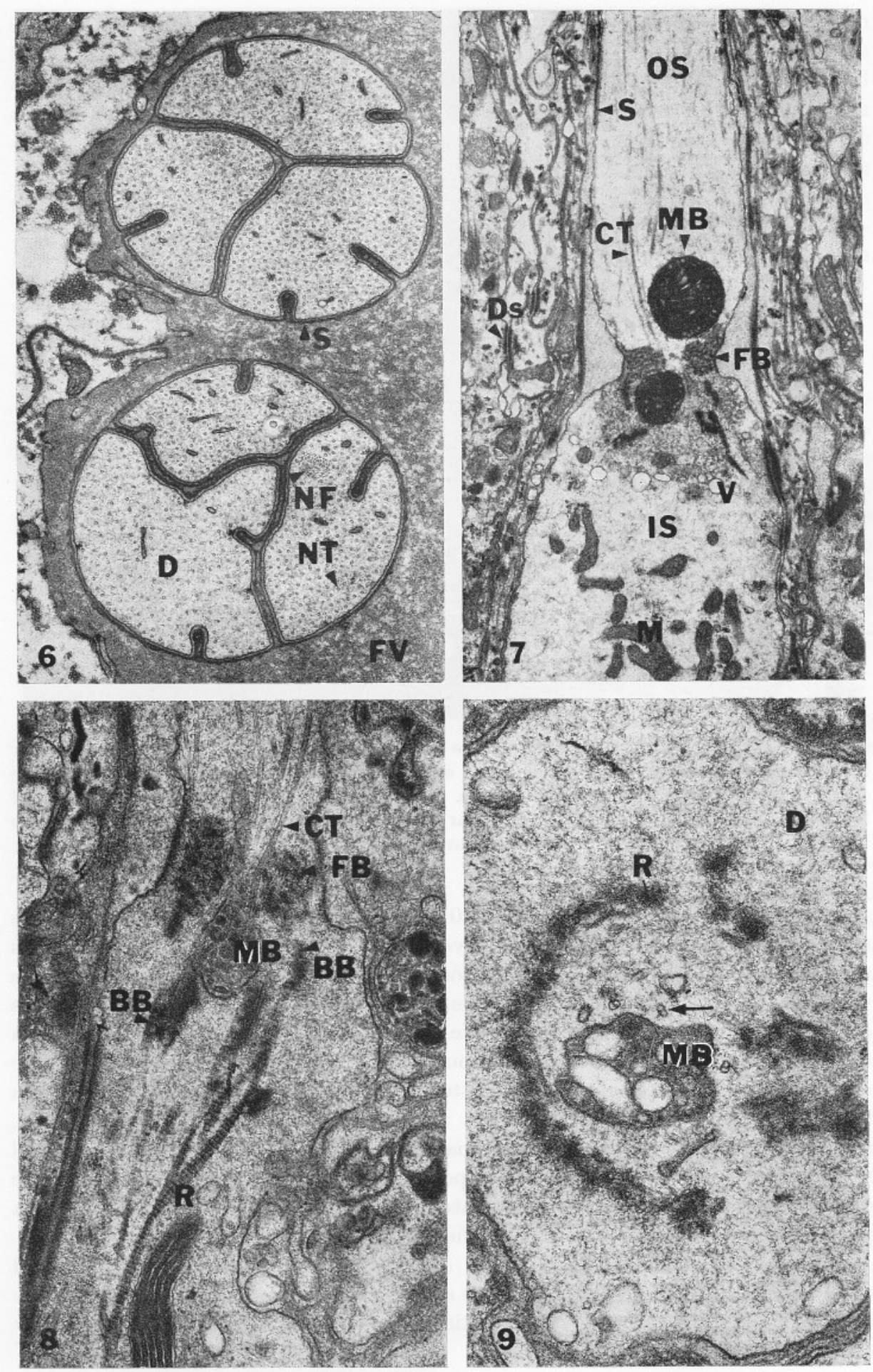

Figs. 6-9 

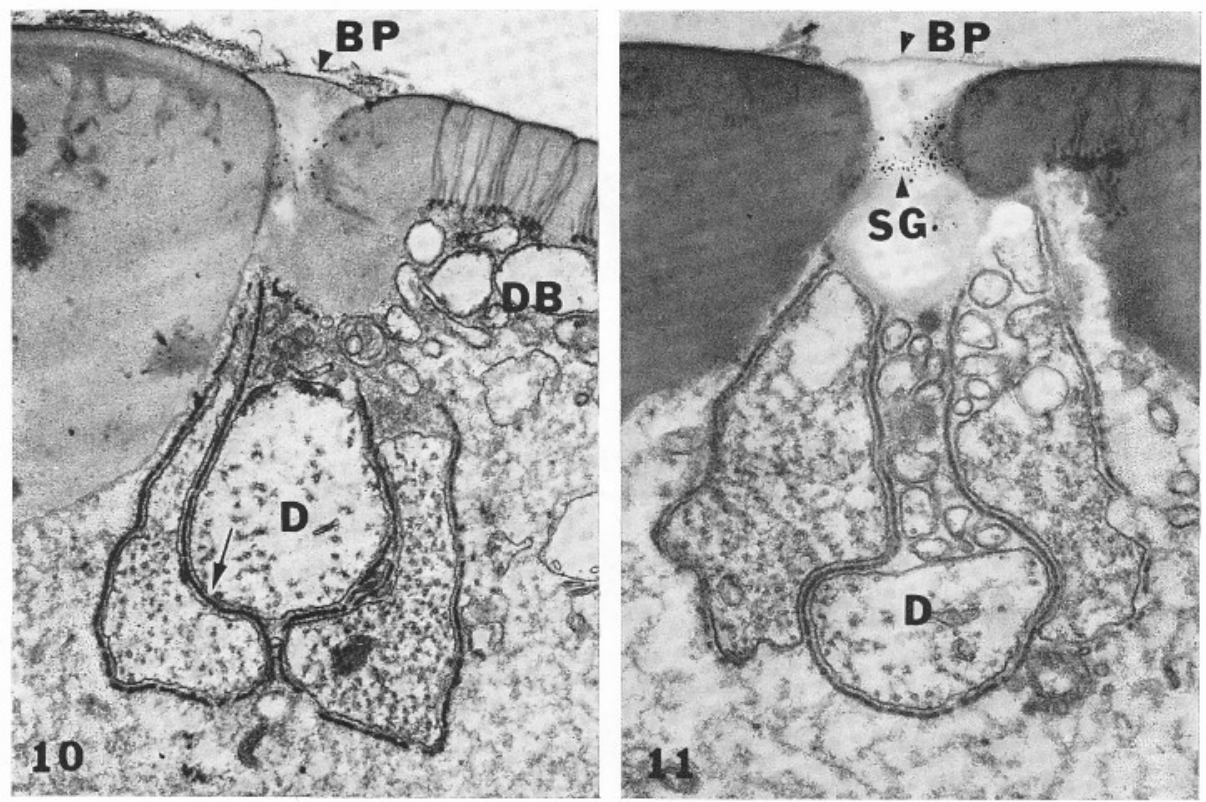

Fig. 10. Oblique section through a basal pore $(B P)$ showing one bundle of 3 dendrites $(D)$ close to the basal pore. The scolopales fuse in the distal region (arrow). $D B$ dendritic branches. $\times 19400$

Fig. 11. Transverse unstained section through a basal pore $(B P)$ after silver-protein treatment of the living larva. Silver granules $(S G)$ accumulated in the neck of the basal pore. $\times 20500$

Lateral Pore Receptor. The lateral pore receptor is easily observed by SEM (Fig. 19) and its location was detected with the light microscope after a $\mathrm{AgNO}_{3}$ solution was applied to the external surface of the dorsal organ. It is located laterally in the invagination between the dome and the cylindrical portion (Figs. 1, 3, 16) and is innervated by two bipolar neurons (Figs. 5, 17). Their dendrites terminate in a cuticular tube (Figs. 16, 18) which has an opening $(0.2 \mu$ in diameter) at the tip. Both dendrites are exposed to the exterior.

Fig. 6. Transverse section through two bundles of 3 dendrites $(D)$ each, at the level of the cylindrical portion. These dendrites innervate the dome. Each dendrite is enclosed individually by a scolopale $(S)$, which is separated from the plasma membrane of the dendrite by a narrow extracellular space. $F V$ fluid-filled vacuole, $N F$ neurofilament, $N T$ neurotubule. $\times 15000$

Figs. 7 and 8. Longitudinal sections of a dendrite at the level of the ciliary region. The constricted ciliary region divides the dendrite into an inner $(I S)$ and an outer segment $(O S)$. Fibrillar body $(F B)$ and multivesicular bodies $(M B)$ are conspicuous features in this region. $B B$ basal body, $C T$ ciliary tubules, $D s$ desmosome, $M$ mitochondria, $R$ rootlet, $S$ scolopale,

$$
V \text { vesicle. } \times 10000 ; \times 26800
$$

Fig. 9. Transverse section of a dendrite $(D)$ proximal to the basal body. Note the double-ciliary tubules (arrow) are around the multivesicular body $(M B)$ and the circular arrangement of the rootlets $(R) . \times 38750$ 


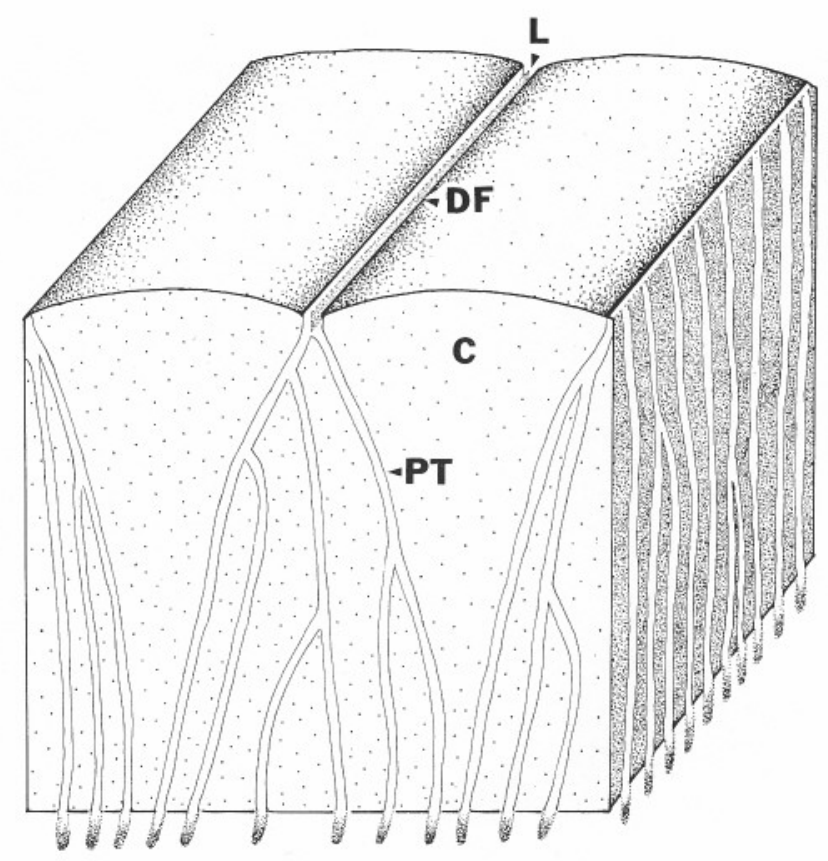

$0.5 \mu$

Fig. 12. Diagram of the arrangement of the pore-tubule system $(P T)$ in the cuticular dome wall $(C) . D F$ ditch-like furrow; $L$ electron-dense line

The two dendrites are encased separately by a scolopale but more distally they are closely enveloped by only one scolopale (Fig. 17). Both dendrites are embedded in an intercellular fluid vacuole formed by a trichogen cell. A tormogen cell, in turn, surrounds the trichogen cell and outside these two concentric sheath cells lie other supporting cells with electron-dense cytoplasm (Fig. 5).

Scolopidium-Like Receptor. A single scolopidium-like receptor is situated in the invagination between the dome and the cylindrical portion, close to the lateral pore receptor (Figs. 3, 16), and innervated by one bipolar neuron. The fine structure of this receptor is similar to that of the scolopidia in the lace wing Chrysopa (Schmidt, 1969), except that the distal tip of this dendrite may be exposed to the exterior through an opening. Although a section precisely through the pore opening was not obtained, other sections strongly suggest an opening (Fig. 20). $\mathrm{AgNO}_{3}$ solution left a dark spot at the site of the suspected pore opening.

The tubular body, which at higher magnification has a mottled appearance, contains numerous microtubules and an electron-dense mass (Fig. 20). In the ciliary region, the dendrite is surrounded by a number of scolopale rods which are not continuous with the scolopale enclosing the outer segment (Fig. 16). Two sheath cells, a trichogen and a tormogen cell, envelope the dendrite.

Contact Chemoreceptors. Two presumed contact chemoreceptors are present in the invagination between the dome and the cylindrical portion (Figs. 3, 16). The 

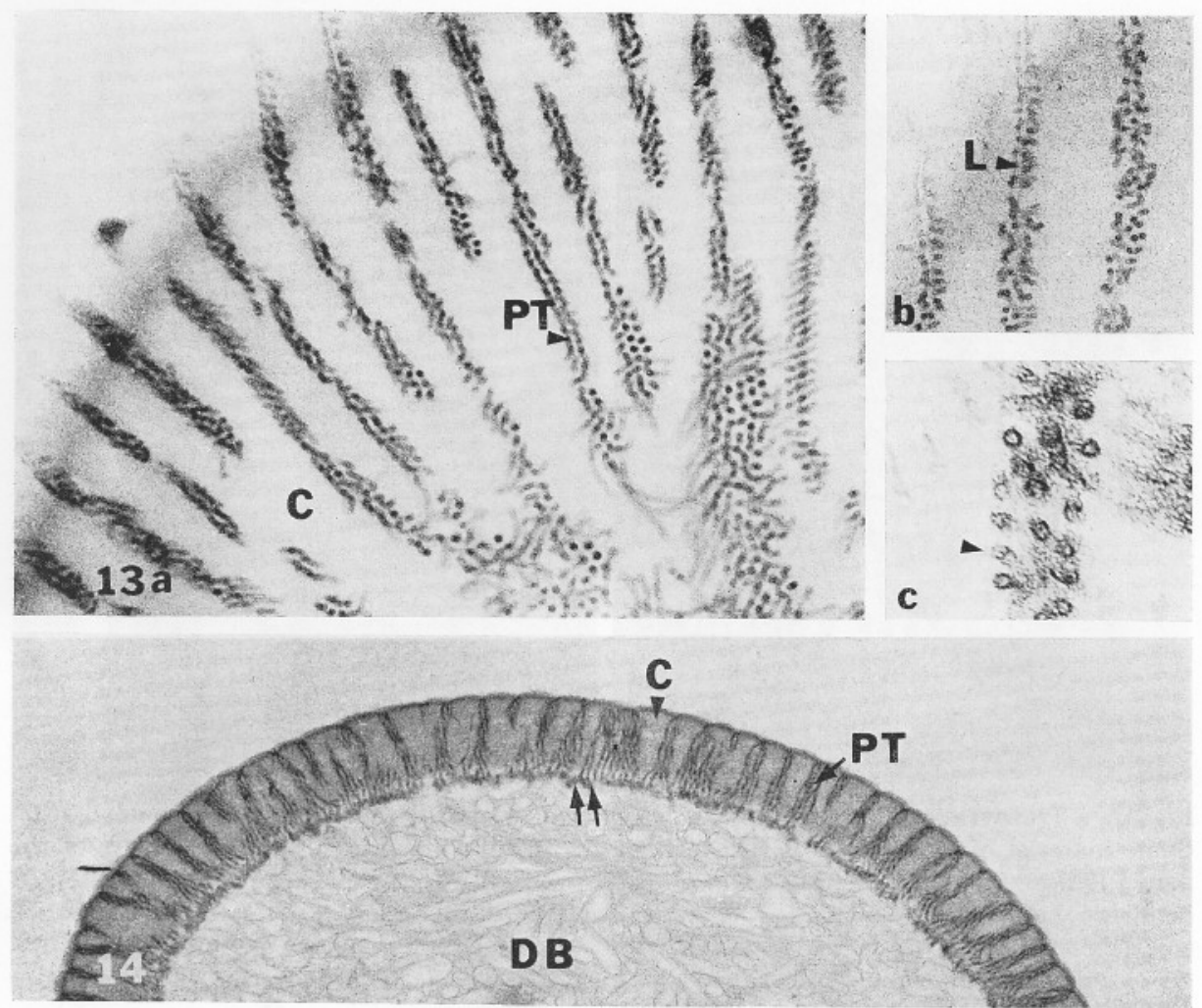

Fig. 13. a Tangential section of the dome wall $(C)$ showing the pore tubules $(P T)$ arranged in rows. $\times 38000$. b Fine electron-dense line $(L)$ in the furrow. $\times 45500$. c Transverse section of pore tubules showing the electron-dense filament inside (arrow). $\times 130000$

Fig. 14. Transverse unstained section of the dome showing a relatively electron-dense poretubule system (PT) and inward extensions of the pore tubules (arrows). $C$ cuticular dome wall, $D B$ dendritic branches. $\times 14000$

site of the pore opening can be detected in the light microscope by means of $\mathrm{AgNO}_{3}$ treatment. Both receptors are identical in their fine structure and supplied by two bipolar neurons. One of the two dendrites terminates in the invagination where it is enclosed by a cuticular tube that opens to the exterior $(0.1 \mu$ in diameter). The other dendrite is shorter and ends in the cylindrical portion without reaching the pore opening. A scolopale envelopes each dendrite separately, but at the region where the shorter dendrite terminates, the two scolopales fuse. At least one, possibly two, sheath cells surround the dendrites concentrically.

Unclassified Receptors. Two unclassified receptors with the same structure occur in the invagination between the dome and the cylindrical portion (Figs. 3, 16). Each receptor is innervated by two bipolar neurons. The conspicuous feature of this receptor is that one of the dendrites contains a "tubular body" at the distal tip whereas the tip of the other dendrite has some granular material with very few neurotubules (Fig. 21). Proximal to this granular material, the neuro- 

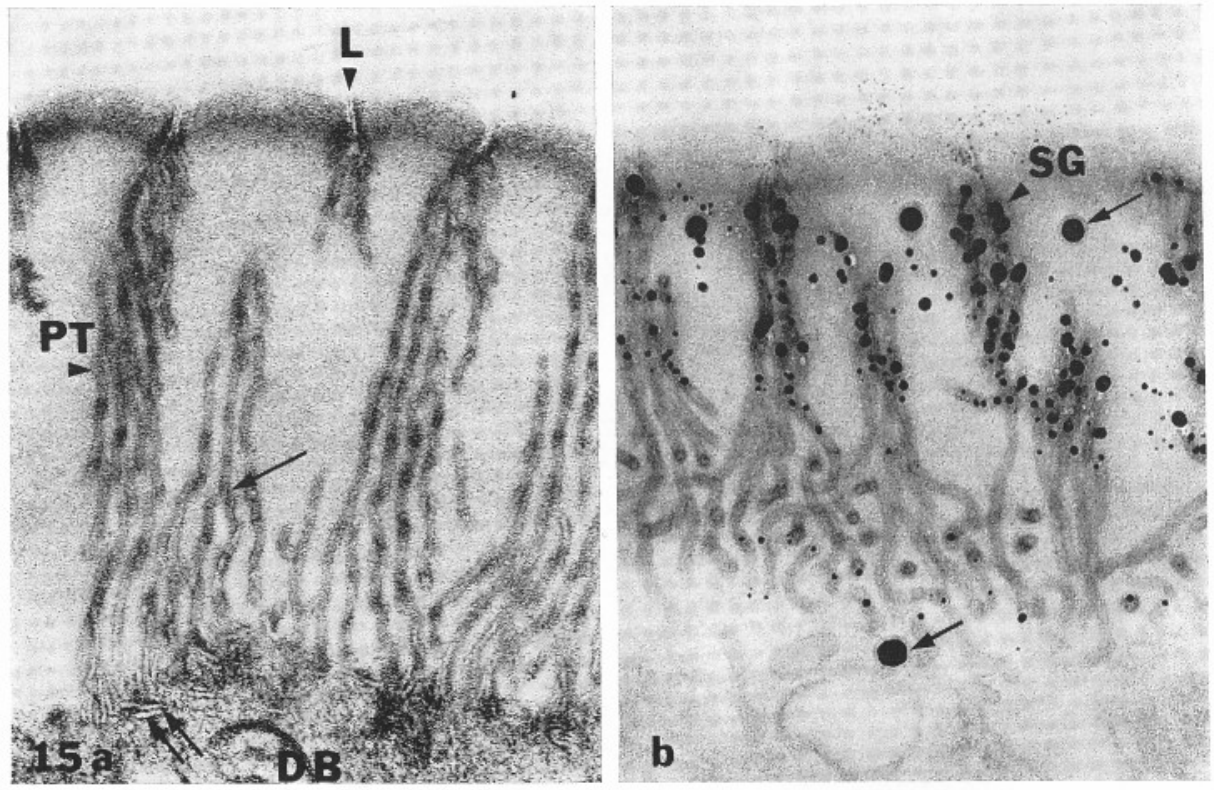

Fig. 15. a Transverse section of several rows of the pore-tubule system $(P T)$ in the dome wall. Some material of relatively low electron density (double arrows) fills the inner part of the pore tubules. $L$ electron-dense line in the furrow; single arrow, pore tubule branches; $D B$ dendritic branches. $\times 78000$. b Unstained section of the dome wall after silver-protein treatment of the living larva. Silver granules $(S G)$ are mostly located in the pore tubules.

Some silver granules can aggregate and form large particles (arrow). $\times 78000$

tubules are more abundant. Only the dendrite containing granular material is exposed to the exterior through an opening $(0.12 \mu$ in diameter $)$. The dendrites, each enveloped by one scolopale, are surrounded by concentrical sheath cells.

\section{Ganglion}

The ganglion, which is referred to as the "pear-shaped portion" by Richter (1962), is situated beneath the epidermis in the interior of the cephalic lobe (Fig. 2). It is composed of bipolar neurons, glial cells, trichogen and tormogen cells, epidermal cells, tracheolar cells and some sheath cells of uncertain origin.

The distal part of the ganglion possesses a large fluid-filled vacuole in its center. This flask-shaped vacuole extends distally into the lumen of the dome. Several formative cells with short microvilli border the fluid-filled vacuole and probably secrete droplets into the vacuole. This cell type can be distinguished from the others by the large round nuclei situated at the bottom of the vacuole, an extensive rough endoplasmic reticulum, myelin-like bodies and numerous mitochondria. The chromatin of the nucleus appears coarsely and irregularly distributed. They are similar to the trichogen or tormogen cells in the sensory hairs of insects and have apparently the same secretory function. Tracheolar cells are present between these cells and the neuron mass. 

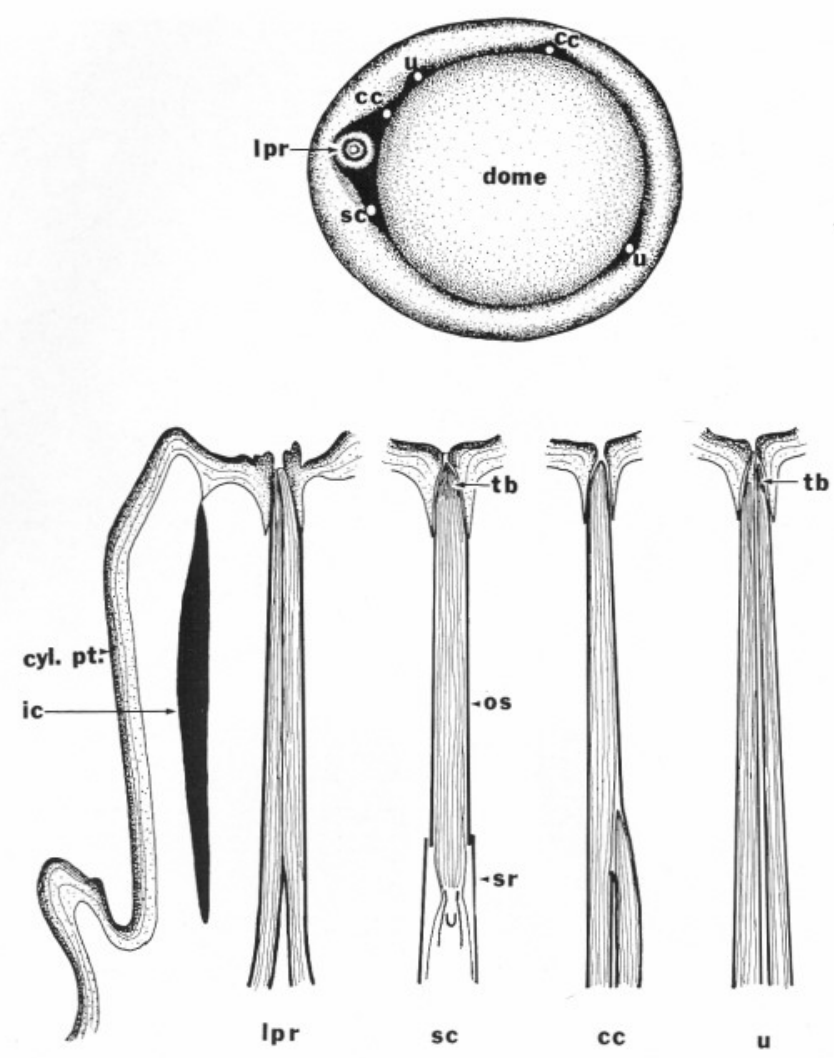

Fig. 16. Diagrams of the position and the structure of the four receptors surrounding the dome. Top: position of the receptors as viewed from the tip of the dorsal organ. Bottom: structure of the four receptors. $c c$ contact chemoreceptor, $c y l$. pt. cylindrical portion, $i c$ inner cuticular ring, $l p r$ lateral pore receptor, $o s$ outer segment, $s c$ scolopidium-like receptor, $s r$ scolopale rods, $t b$ tubular body, $u$ unclassified receptor

The proximal part of the ganglion is mainly composed of a neuron mass and glial cells. All the perikarya of the bipolar neurons (about 35-41) innervating the dorsal organ are located in this neuron mass. The neurons have comparatively large oval nuclei and sparse cytoplasm. The axons (about $0.7 \mu$ in diameter) arising from their neurons leave the ganglion proximally as a solid nerve.

The neuron mass is enclosed peripherally by glial cells whose processes extend inward and spiral several times around both the perikarya and axons. Several envelopes separate the perikarya and axons. Morphologically, these envelopes correspond to the "tunicated" type of sheath cells (Smith, 1968) which are intermediate between the myelinated and unmyelinated nerves of vertebrates. The lateral membranes of glial cells diverge leaving extensive extracellular channels between them. Some of the channels show periodic lacunae; some become closely joined by various desmosomes and tight junctions. These glial 

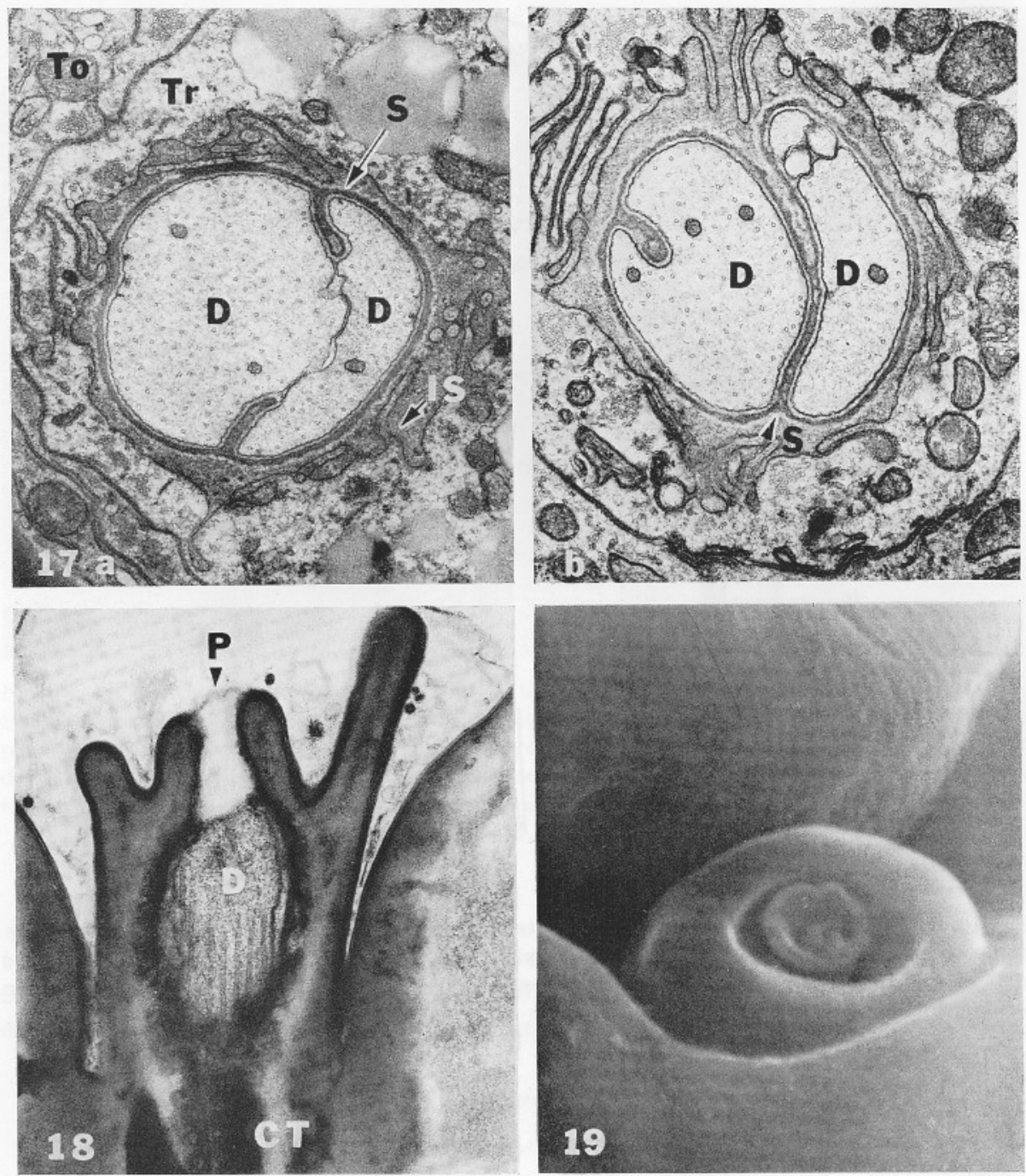

Fig. $17 \mathrm{a}$ and b. Transverse section of the two dendrites innervating the lateral pore receptor. a At the distal level of the cylindrical portion, the dendrites $(D)$ are enclosed by one scolopale (S). IS intercellular space, To tormogen cell, $T r$ trichogen cell. $\times 20000$. b At the proximal level of the cylindrical portion, the dendrites $(D)$ separate and each is surrounded by a scolopale. $\times 20000$

Fig. 18. Longitudinal section through the pore $(P)$ in the tip of the lateral pore receptor. Distally the dendrites $(D)$ (see Figs. 20, 21) are naked and freely exposed to the exterior. $C T$ cuticular tube. $\times 26000$

Fig. 19. Lateral pore receptor. SEM, $\times 7000$

cells are similar to the perineurium of insect nerves described by Maddrell and Treherne (1967), and Smith (1967). The glial cytoplasm extends into the cylindrical portion and forms two layers surrounding the inside of the cuticular 

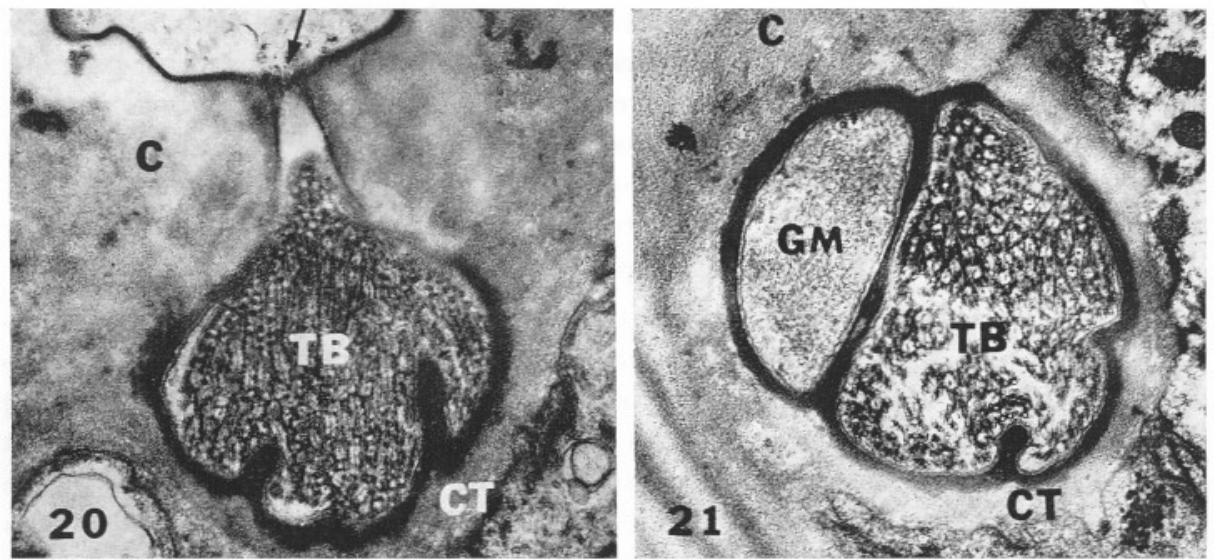

Fig. 20. Oblique section through the tip of a scolopidium-like receptor, showing the tubular body $(T B)$ of the dendritic ending. Unlike the scolopidia this receptor might possess an opening (arrow) communicating to the exterior. $C$ cuticle, $C T$ cuticular tube. $\times 21000$

Fig. 21. Transverse section through the dendritic tips of an unclassified receptor. One contains some granular material $(G M)$ with very few neurotubules whereas the other has a tubular body $(T B) . \times 11500$

ring (Figs. 3,5). The nerve of the dorsal organ is ensheathed by glial cells and the axons are separately encircled by the glial cell sheath.

Some flattened cells with elongated nuclei and relatively electron-dense cytoplasm surround the middle part of the ganglion (Fig. 2). The cytoplasm of these cells contains unusually large bundles of microtubules which attach to the cuticular invagination. This high density of microtubules suggests a skeletal function maintaining the form of the ganglion.

\section{Discussion}

From the behavioral experiments performed by Bolwig (1946) and the fine structure, it is reasonable to assume that the dome of the dorsal organ is an olfactory receptor. Like the thin-walled olfactory pegs in insects (Slifer, 1967), the dome is supplied by a number of bipolar neurons, and its cuticular wall contains many pores.

After a long period of uncertainty whether the cuticle of chemoreceptors in insects is permeable or not, Slifer et al. (1957) demonstrated definite pores in the cuticular wall. However, another question remains: What is the relationship between the receptive dendrite and the exterior? Slifer et al. (1959) assumed that fine extensions of the dendritic branches fill the pore tubules and are in direct contact with the air. Recently, Ernst (1969) obtained clear evidence that the pore tubules (in olfactory sensilla of a beetle) are cuticular in origin and not extensions of dendritic branches. He exposed the sensilla to a silver-protein solution and demonstrated that the silver granules penetrate through the pore tubules into the hemolymph. Using the same technique, we obtained similar results with the 
dorsal organ of the house fly larva. The wall of the dome is perforated by a complex pore-tubule system. The dimensions of the pore tubules are very similar to those described by Ernst, but the arrangement is different (hexagonal pattern in the beetle sensillum, rows in the dorsal organ of the fly larva). Since some of the extensions of pore tubules were quite close to dendritic branches, direct connections are suspected as demonstrated by Myers (1968) and Steinbrecht (1970). The role of the filament in the pore tubules is not known.

Seven "basal pores" were found encircling the base of the dome. There is no evidence of a sensory function, since silver granules did not penetrate into the dome through the basal pores. The pores which Viallanes (1882, plate 4, Fig. 2) observed at the base of the dorsal organ of Eristalis larvae are probably analogous to these basal pores in the house fly larvae. These pores are very similar to the "basal spots" of thin-walled pegs described by Slifer and Sekhon (1963) who stated that the scolopales (i.e., "cuticular sheaths") are pulled out through these basal spots during molting. Although no continuity was observed between the basal pore and scolopales in our preparations, some relationship probably exists since the scolopales turn towards the basal pore and disintegrate only on this outer side. It seems reasonable to assume that the scolopale originates from the site of the basal pore since little or no scolopale is present above the level of the basal pores.

The previously undescribed "lateral pore receptor" is innervated by two dendrites whose tips are exposed to the exterior through a single opening. It resembles the thick-walled chemoreceptor of many insects by having only a single pore and few unbranched dendrites. Therefore, it may serve as a contact chemoreceptor (Dethier, 1955; Dethier et al., 1963) and/or react to strong odors (Slifer, 1954, 1956; Hopkins, 1964).

The invagination between the dome and the cylindrical portion contains three other types of receptors. The "scolopidium-like receptor" is very similar to known mechanoreceptors, such as the tactile bristles in the honey bee (Thurm, 1964 ) and the scolopidia in the lace wing (Schmidt, 1969). However, the dendritic tip appears to be exposed to the exterior and hence, this receptor may possibly serve both as a mechanoreceptor and as a contact chemoreceptor. Two of the other receptors located in the invagination are probably "contact chemoreceptors", since the dendritic tip is exposed to the exterior through a single opening. The "unclassified receptor" type is represented by two sensilla which are innervated by two dendrites each. The dendritic tip which is exposed to the exterior may be a chemoreceptor, while the other dendrite with a tubular body ending near the opening may be a mechanoreceptor.

The presence of five different types of receptors indicates that the dorsal organ is more complex than previously thought. As a hypothesis, we assume that the dome of the dorsal organ is an olfactory receptor while the unbranched receptors having a pore opening to the exterior are involved in contact chemoreception. Those receptors which possess a tubular body in their dendritic endings probably serve a mechanoreceptive function. Since the dorsal organ contains $35-41$ axons but only 32 dendrites were found in the cylindrical portion, there may be other receptors. 
In addition to Muscidae, we have observed the three pairs of sensory organs (dorsal, terminal, and ventral) in the cephalic lobes of larvae of Saroophagidae, Calliphoridae, and Chloropidae. The anterior sensory organs of the house fly larva probably are typical of all higher Diptera, but this must be verified by comparative studies.

\section{References}

Bolwig, N.: Senses and sense organs of the anterior end of the house fly larvae. Vid. Medd. dansk nat.-hist. Foren 109, 81-217 (1946).

Dethier, V. G.: The physiology and histology of the contact chemoreceptors of the blowfly. Quart. Rev. Biol. 30, 348-371 (1955).

- Larsen, J. R., Adams, J. R.: The fine structure of the olfactory receptors of the blowfly. In: Olfaction and taste, ed. by Y. Zotterman. Proc. Intern. Symp. Wenner-Gren Center, 1st, Stockholm. New York: MacMillan 1963.

Ernst, K.-D.: Die Feinstruktur von Riechsensillen auf der Antenne des Aaskäfers Necrophorus (Coleoptera). Z. Zellforsch. 94, 72-102 (1969).

Hopkins, B. A.: The probing response of Stomoxys calcitrans (L.) (the stable fly) to vapours. Animal Behaviour. 12, 513-524 (1964).

Ludwig, C. E.: Embryology and morphology of the larval head of Calliphora erythrocephala (Meigen). Microentomol. 14, 75-111 (1949).

Maddrell, S. H. P., Treherne, J. E.: The ultrastructure of the perineurium in two insect species, Carausius morosus and Periplaneta americana. J. Cell Sci. 2, 119-128 (1967).

Moulins, M.: Les sensilles de l'organe hypopharyngien de Blabera craniifer Burm. (Insecta, Dictyoptera). J. Ultrastruct. Res. 21, 474-513 (1968).

Myers, J.: The structure of the antennae of the Florida queen butterfly, Danaus gilippus berenice (Cramer). J. Morph. 125, 315-328 (1968).

Palade, G. E.: A study of fixation for electron microscopy. J. exp. Med. 95, 285-297 (1952).

Richardson, K. C., Jarret, L. J., Finke, E. H.: Embedding in epoxy resins for ultrathin sectioning in electron microscopy. Stain Technol. 35, 313-323 (1960).

Richter, S.: Unmittelbarer Kontakt der Sinneszellen cuticularer Sinnesorgane mit der Außenwelt. Eine licht- und elektronenmikroskopische Untersuchung der chemorezeptorischen Antennensinnesorgane der Calliphora-Larven. Z. Morph. Okol. Tiere 52, 171-196 (1962).

Schmidt, K.: Der Feinbau der stiftführenden Sinnesorgane im Pedicellus der Florfliege Chrysopa Leach (Chrysopidae, Planipennia). Z. Zellforsch. 99, 357-388 (1969).

Slifer, E. H.: The reaction of a grasshopper to an odorous material held near one of its feet (Orthoptera: Acrididae). Proc. roy. Entomol. Soc. London, Ser. A. 29, 177-179 (1954).

- The response of a grasshopper, Romalea microptera (Beauvois), to strong odours following amputation of the metathoracic leg at different levels. Proc. roy. Entomol. Soc. London, Ser. A. 31, 95-98 (1956).

- The thin-walled olfactory sense organs on insect antennae. In: Insects and physiology, ed. by J. W. L. Beament and J. E. Treherne. Edinburgh and London: Oliver \& Boyd 1967.

- Prestage, J. J., Beams, H. W.: The fine structure of the long basiconic sensory pegs of the grasshopper (Orthoptera, Acrididae) with special reference to those on the antenna. J. Morph. 101, 359-397 (1957).

_ _ - The chemoreceptors and other sense organs on the antennal flagellum of the grasshopper (Orthoptera: Acrididae). J. Morph. 105, 145-191 (1959).

- Sekhon, S. S.: Sense organs on the antennal flagellum of the small milkweed bug, Lygaeus kalmii Stal (Hemiptera, Lygaeidae). J. Morph. 112, 165-193 (1963).

Smith, D. S.: The trophic role of glial cells in insect ganglia. In: Insects and physiology, ed. by J. E. Treherne and J. W. L. Beament. Edinburgh and London: Oliver \& Boyd 1967.

— Insect cells. Edinburgh: Oliver \& Boyd 1968.

- The fine structure of haltere sensilla in the blowfly, Calliphora erythrocephala (Meig.), with scanning electron microscopic observations on the haltere surface. Tissue \& Cell. 1, 443-484 (1969).

Z. Zellforsch., Bd. 117 
Steinbrecht, R. A.: Stimulus transferring tubules in insect olfactory receptors. 7ième Congr. Int. Microsc. Electr., Grenoble. 947-948 (1970).

Thurm, U.: Mechanoreception in the cuticle of the honey bee: Fine structure and stimulus mechanism. Science 145, 1063-1065 (1964).

Venable, J. H., Coggeshall, R. E.: A simplified lead citrate stain for electron microscopy. J. Cell Biol. 25, 407-408 (1965).

Viallanes, M. H.: Recherches sur l'histologie des insectes et sur les phénomènes histologiques qui accompagnent le developpement postembryonnaire de ces animaux. Ann. Sci. Nat. (Zool.) 14, 1-348 + Pl. 1-18 (1882).

Xotejadded to proof: An article/ by Sobtt and Zacharuk (Ćanad. J./Zool. 49. 199-210, 1971) appeared affer this paper was in press. Theiy description of the fine structure of the antennal sensoryl appendix of a beetle larvae (Elateridae) is similar to that of the dorsal organ of the fly larva.

I-Wu ohu and B. C./Axtell

Department of/Entomology

North Carolina State University

Raleigh, N,C. 27607, U.S.A. 